\title{
支部報 告
}

\section{○州地方会}

昭和 39 年 11 月 1 日・ 2 日の雨日, 北九州市小倉区新小 倉ビルホールにおいて, 第18回九州地方会を開催した. 両日にわたって行なわれた特別講演及び会員研究発表は 次の通りである。

11月 1 日.……会員研究発表 1) 21)

11月 2 日 ……会員研究発表 22）～27)

特別講演

（1）最近の放射線治療のすう勢

$$
\text { 九大教授 }
$$

入江英雄博士

（2）古いレントゲン技術についての反省

久留米大学長

古賀良彦博士

\section{○会員研究発表}

\section{1）コバルト治療室の構造並びに防護と関係法規}

九州厚生年金病院

田中 高生

目的 : コバルト治療室の構造及び防護を関係法規之参 照し，使用施設の改善を計る。

当院にて使用中のコバルト治療に伴なう使用施設の構 造及び防護の状況を報告するととむに，関係法規を参照 し，次のことを行なった。

1.コバルト治療汇伴なう関係法規の検討

2. 使用施設の構造及び防護基準の設定

3. 使用施設の遮敕能力の計算

4. 漏洩線量測定々防護壁の補修

6. 管理区域の設定

6.コバルト照射中，コバルト照射装置とドアスイッ チを連動して，その旨の自動表示装置の設置

\section{2）コバルト治療室の構造並びに散乱線について}

麻生産業 $\mathrm{KK}$ 飯塚病院

鬼塚 宏太

当飯塚病院では昭和36年 6 月よりコバルト治療を行な

って扔り, 装置は島津製 RT-10,000 型, 線源はカナダ 製ペレットタイプ 1,000C を購入した.

治療室の構造の概略について述へ，また線源搬入直後 の漏洩線・散乱線の測定結果を報告する.

\section{3） X線障害について}

旭硝子牧山診療所

4）新方式によるネームプリンターの研究

門司労災病院

○門田岩夫・佐藤 渉・真鍋嘉宏

$\mathrm{X}$ 線写真診断に便利なよう患者の氏名・撮影年月日等
をフィルムに直接焼付的る方法は, 従来各方面で研究, 改良されているが，我々は各科から放射線科湜出され る照射嘎の氏名等をそのままフィルムに燃付ける方法を 採用し，その目的に適ったプリンターを製作し現在使用 しているので，概略を報告する。

I . 原 理

撮影後のフィルムの隅に末感光部分をつくり，乙の部 分に氏名, 撮影年月日等必要事項を弱電で露光して焼付 現像する方式である。

П. 構 造

金属製器で緥 $40 \mathrm{~cm}$ ，横 $31 \mathrm{~cm}$ ，高さ $11 \mathrm{~cm}$ で照射箩を プリンター下端に合わせるとプリント䇢所が露光部分に 一致する様にした。

П. 結 果

当院で使用している照射篦はかなり厚い紙質であるが， この紙に記入された必要事項がフィルムの下端または左 右の隅に明暸にプリントされ, 撮影後の処理が簡単にな った.プリンターの製作も簡単で労力の節約と, 正確に フィルム上に必要事項がプリントされる利点がある.

\section{5）測微光度計による骨菱縮 X 線像の解析} 九州厚生年金病院

增 野 豊・岡部 健吾・田中 高生・ 岡田 寅彦・ ○吉武清秀・堀尾 重治・ 松尾 春生

我々は第 1 報「骨折による骨萎縮推移のX線写真解明」 (第20回日放技総会発表) 亿於て骨萎縮 X線写真の解明に 測微光度計を用いる計測法が誩断上有意義であるととを 述べた.上述の課題の一つの問題点として, 測定部位に 如何なる slit 幅を用いれば最も適合するかについて基礎 実験を行なう必要があるので，骨組織のX線像に近似之 見なされる様な間隔に近いと思われる金網を選定してX 線像を作り，とれを測微光度計で計測し，検討したので 報告する。

基礎実験一一薬局方 19 の節第 5，6，7 号をアル之カイ ルの下に置き撮影した。撮影条件 $60 \mathrm{kVp}$ (半価層 $\mathrm{Al}$ $2.5 \mathrm{~mm}$ ), $5 \mathrm{mAs}$, F.P.D. $150 \mathrm{~cm}$ (他の条件は省略する). 実験結果及び考察——スリット幅を $0.05 \mathrm{~mm}, 0.045$ $\mathrm{mm}, 0.024 \mathrm{~mm}$ に変化させてX線像を測定した所，線間 距離の約 $1 / 2$ の幅のスリットを用いれば，ほぼ目的を達す る事が出来るようである。一般には $0.045 \mathrm{~mm}$ のスリッ 卜幅とし，移動距離はそのスリット幅より数\%大きくと ればよいと思われる，尚測定部位によって適切なスリッ 